\title{
MENINGKATKAN PERAN MASYARAKAT MELALUI PROGRAM PENDIDIKAN BERBASIS TAUHID DALAM PEMBANGUNAN DESA YANG MANDIRI, KREATIF DAN BERBUDAYA
}

\section{IMPROVING THE ROLE OF COMMUNITIES THROUGH TAUHID-BASED EDUCATION PROGRAMS IN SUPPORT OF INDEPENDENT, CREATIVE AND CULTURED VILLAGE DEVELOPMENT}

\author{
Widyasari'ia dan N Maryani² \\ ${ }_{1}^{1}$ Program Studi Pendidikan Guru Sekolah Dasar, Fakultas Keguruan dan Ilmu Pendidikan, \\ Universitas Djuanda Bogor, Jl. Tol Ciawi No.1 Kotak Pos 35 Bogor 16720 \\ 2Program Studi Manajemen Pendidikan Islam, Fakultas Keguruan dan Ilmu Pendidikan, \\ Universitas Djuanda Bogor, Jl. Tol Ciawi No.1 Kotak Pos 35 Bogor 16720 \\ a Korespondensi: Widyasari, Email: widyasari@unida.ac.id \\ (Diterima: 20-12-2016; Ditelaah: 22-12-2016; Disetujui: 17-02-2017)
}

\begin{abstract}
Real Work Lecture (KKN) is one form of the realization of Tri Dharma Perguruan Tinggi that is dedication, as an effort to improve the index of community development through the work and real proof. KKN activity is expected to be a facilitator for the community in enhancing its role through the tauhid-based education program in the development of an independent village, creative and cultured. Students participating KKN FKIP Djuanda University empower the Ciburial community of Tugu Utara village to play a role in the tauhid-based education program through Smart Learning Park for young children and in the development of waste bins to answer the needs of facilities and infrastructure of villagers ciburial RT 02 RW 05 who had been throwing away trash to ciliwung times. Both programs are held students of KKN FKIP Djuanda University is very warmly welcomed and craved by the citizens of Ciburial North Tugu Village.
\end{abstract}

Keywords: community role, education program, KKN Kreatif.

\begin{abstract}
ABSTRAK
Kuliah Kerja Nyata (KKN) merupakan salah satu bentuk perwujudan dari Tri Dharma Perguruan Tinggi yakni pengabdian, sebagai upaya peningkatan indeks pembangunan masyarakat melalui karya dan bukti nyata. Kegiatan KKN diharapkan mampu menjadi fasilitator bagi masyarakat dalam meningkatkan perannya melalui program pendidikan berbasis tauhid dalam pembangunan desa yang mandiri, kreatif dan berbudaya. Mahasiswa peserta KKN FKIP Universitas Djuanda memberdayakan masyarakat Ciburial Desa Tugu utara untuk berperan dalam program pendidikan berbasis tauhid lewat Taman Belajar Cerdas Ceria untuk anak usia dini dan dalam pembangunan bak sampah untuk menjawab kebutuhan sarana dan prasaranan warga kampung ciburial RT 02 RW 05 yang selama ini membuang sampahnya ke kali Cliwung. Kedua program yang diadakan mahasiswa KKN FKIP Universitas Djuanda ini sangat disambut hangat dan didamba-dambakan oleh warga Ciburial Desa Tugu Utara.
\end{abstract}

Kata kunci: peran masyarakat, program pendidikan, KKN Kreatif

Widyasari dan N Maryani. 2017. Meningkatkan peran masyarakat melalui program pendidikan berbasis tauhid dalam pembangunan desa yang mandiri, kreatif dan berbudaya. Qardhul Hasan: Media Pengabdian kepada Masyarakat 3(1): 39-45. 


\section{PENDAHULUAN}

Kuliah Kerja Nyata (KKN) merupakan salah satu kegiatan wajib yang dicanangkan oleh pemerintah dalam melaksanakan tri dharma perguruan tinggi yang kedua yaitu pengabdian kepada masyarakat. saat ini tugas mahasiswa melaksanakan pengabdian kepada masyarakat di Desa Tugu Utara untuk mengaplikasikan semua ilmu yang telah didapatkan dalam proses pendidikan dan pengajaran.

Peran serta masyarakat dalam pendidikan sangatlah penting, masyarakat dapat berperan serta sebagai sumber pelaksana dan pengguna hasil pendidikan. Menurut UU RI nomor 20 Tahun 2003 tentang Sistem Pendidikan Nasional, komite sekolah/madrasah adalah lembaga mandiri yang beranggotakan orangtua/wali peserta didik, komunitas sekolah, serta tokoh masyarakat yang peduli pendidikan. Tidak hanya pendidikan umum saja, pendidikan Islam juga berperan penting untuk pengembangan akhlak dan memupuk moral anak-anak, konsep pendidikan dalam Islam memiliki tiga terminologi, yaitu tarbiyyah, ta'lim dan ta'dib. Dengan demikian yang dimaksud pendidikan berbasis tauhid adalah keseluruhan kegiatan pengajaran, pendidikan bimbingan, pembinaan dan pengembangan potensi diri yang kemudian diaplikasikan dalam kehidupan dan dipersembahkan sebagai bentuk pengabdian dan kepatuhan kepada Allah. Upaya ke arah itu diawali dari menanamkan nilai-nilai akhlakul karimah (pendidikan karakter, budi pekerti, etika, moral sopan santun atau tata krama) dalam diri setiap peserta didik kemudian diimplementasikan melalui peran kekhalifahan sebagai pemakmur dan pemelihara kehidupan di dunia.

Selain itu pemanfaatan masyarakat untuk memajukan desa sangatlah diharapkan, masyarakat yang berkualitas sangat penting karena tanpa adanya sumber daya manusia tidak akan ada pemanfaatan sumber daya alam yang baik. Oleh karena itu pendidikan menjadi hal yang mutlak yang harus dilaksanakan. Beberapa permasalahan yang di hadapi oleh masyarakat Desa Tugu Utara kampung Ciburial RT 02/05 antara lain :

1. Keberadaan PAUD di Desa Tugu Utara khususnya di RW 05 masih sangat minim. Serta minimnya Sumber Daya Manusia atau tenaga pengajar PAUD yang hanya lulusan SMA/sederajat. Tentunya pendampingan terhadap guru-guru PAUD tersebut sangat dibutuhkan dan pembentukan kaderisasi-kaderisasi guru PAUD yang berpendidikan tinggi dan berkulaitas.

2. Khusus di RT 02/05 masih banyak warga yang membuang sampah sembarangan seperti membuang sampah ke sungai yang merupakan perilaku yang sangat tidak baik, kurangnya tempat pembuangan akhir dan kurangnya manajemen pengelolaan sampah seperti pengangkutan sampah oleh petugas kebersihan Kabupaten Bogor yang tidak teratur.

Berdasarkan permasalahan tersebut, maka mahasiswa/i KKN ini sangat diharapkan dapat menjadi penggerak bagi masyarakat dalam mengembangkan segala aktifitas-aktifitas berbasis tauhid dan meningkatkan perekonomian serta pendidikan masyarakat. Tujuan pelaksanaan kegiatan KKN FKIP UNIDA ini adalah :

1. Mahasiswa memperoleh pengalaman belajar yang berharga melalui keterlibatan dalam masyakarat yang secara langsung menemukan, merumuskan, memecahkan dan menanggulangi permasalahan pembangunan secara pragmatis interdisipliiner.

2. Mahasiswa dapat memberikan pemikiran berdasarkan ilmu, teknologi dan seni dalam upaya menumbuhkan, mempercepat gerak serta mempersiapkan kader pembangunan.

3. Memberikan pengetahuan dan motivasi kepada masyarakat tentang pentingnya suatu pendidikan. 
4. Untuk mewujudkan pembangunan nyata fasilitas umum dan fasilitas sosial desa guna menjawab kebutuhan pembangunan lingkungan.

5. Memberikan pemahaman tentang ekonomi Islam dan aktivitas-aktivitas ekonomi berbasis tauhid.

\section{MATERI DAN METODE}

\section{Landasan Teoretis}

Sumber daya manusia Menurut Sonny Sumarsono (2003:4) Sumber daya manusia atau human resources mengandung dua pengertian, yaitu :

1. Sumber daya manusia adalah usaha kerja atau jasa yang dapat diberikan dalam proses produksi. Dan sumber daya manusia (SDM) juga mencerminkan kualitas usaha yang diberikan seseorang dalam waktu tertentu untuk menghasil barang dan jasa.

2. Sumber daya manusia, menyangkut manusia yang mampu bekerja untuk memberikan jasa atau usaha kerja. Mampu bekerja berarti mampu melakukan kegiatan yang mempunyai kegiatan ekonomis, yaitu bahwa kegiatan tersebut menghasilkan barang atau jasa untuk memenuhi kebutuhan masyarakat.

3. Sumber daya manusia (SDM) atau manusia menjadi unsur utama dalam setiap aktivitas yang dilakukan. Peralatan yang handal atau canggih tanpa peran aktif sumber daya manusia (SDM) tidak berarti apa-apa.

\section{Rincian Program Kegiatan}

1. TABEL CC (Taman Belajar Cerdas Ceria)

Mencerdaskan serta meningkatkan pengetahuan, keterampilan serta prilaku anak-anak usia sekolah mulai dari tingkat PAUD dan SD.

2. BPLK (Balai Pelatihan Komputer)

Menumbuhkan kemampuan anak akan perkembangan teknologi yang terus berubah dan memotivasi kemampuan anak agar bisa beradaptasi dengan perkembangan teknologi pada saat ini serta mengembangkan potensi belajar berbasis teknologi kepada anak.

3. Pencak Silat

Untuk membentuk masyarakat agar Berjiwa Sehat, Berpikir Cerdas, dan dapat Melestarikan Budaya Asli Indonesia.

4. Pendampingan Guru PAUD

Meningkatkan profesionalisme Guru PAUD dan bentuk partisipasi mahasiswa jurusan keguruan Universitas Djuanda Bogor untuk mewujudkan tanggung jawab sosial di tengah-tengah masyarakat.

5. Seminar Pendidikan

Menumbuhkan kesadaran orang tua akan pentingnya pendidikan bagi anak.

6. Ekstrakurikuler Menari dan menyanyi

Mengasah bakat yang ada pada anak.

7. Pengajian anak-anak

Meningkatkan ketaqwaan terhadap

Tuhan Yang Maha Esa serta mendekatkan mahasiswa dengan masyarakat dan anak-anak kampung ciburial

8. Majelis Ta'lim ibu-ibu

Meningkatkan kualitas keimanan dan ketaqwaan kepada Allah SWT serta meningkatkan ukhuwah (persaudaraan) antar jama'ah majelis ta'lim.

9. Posyandu

Meningkatkan kemampuan masyarakat dalam mengembangkan kesehatan balita.

10. PKM (Penyuluhan Kesehatan Masyarakat)

Menumbuhkan kesadaran masyarakat pentingnya kesehatan dan kebersihan lingkungan

11. Ekonomi kreatif (Bola susu, keripik wortel dan bucket bunga)

Memperkenalkan apa itu ekonomi kreatif yang berupa pengolahan produk rumahan yang sederhana, sehat dan murah serta memberikan pengetahuan baru mengenai jajanan yang sehat, enak dan bernilai ekonomis.

12.17 Agustus 
Meningkatkan kesadaran akan besarnya jasa pejuang kemerdekaan dan nasional dalam merebut kemerdekaan bangsa Indonesia serta mengaktifkan pemudapemudi Ciburial

13. Gotong royong dan Bakti Sosial

Melestarikan budaya bangsa, mempererat hidup saling membantu dan membangun kebersamaan dalam masyarakat.

14. Pembangunan Fisik Desa

Memberikan tempat khusus bagi orangorang yang membuang sampah. Merealisasikan pengelolaan sampah di Kampung Ciburial.

15. Tanaman Hydroponik

Untuk memberikan wawasan tentang bercocok tanam modern kepada anakanak sekaligus mempraktikan langsung bagaimana cara menanam sayuran secara Hidroponik.

16. Pola Hidup Bersih dan Sehat (PHBS)

Meningkatkan pengetahuan, kesadaran, kemauan dan kemampuan anak-anak agar hidup bersih dan sehat.

\section{PHBN HUT RI 72}

Mempererat rasa Nasionalisme bangsa.

\section{Lokasi Pelaksanaan KKN}

Lokasi kegiatan KKN berada di daerah Desa Tugu Utara yang merupakan salah satu Desa di Wilayah Selatan Kabupaten Bogor. Dengan luas wilayah yaitu $1703 \mathrm{Ha}$ dan batas wilayah:

Sebelah Utara : Kec.Sukamakmur

Sebelah : Desa Tugu Selatan

Selatan

Sebelah Barat : Desa Batu Layang

Sebelah : Kecamatan Pacet

Timur Cianjur

Tugu Utara terdiri dari tiga dusun dan terdapat 6 (enam) Rukun Warga dan 24 (Dua puluh empat) Rukun Tetangga, Jumlah Penduduk yaitu 11.048 orang dan Kepala Keluarga terdiri dari $3.150 \mathrm{KK}$.

Desa Tugu Utara merupakan desa yang terletak pada ketinggian permukaan laut
650-1200 M dan tingkat curah hujan 3178 $\mathrm{MM} /$ thn serta kelembaban dengan suhu rata-rata $23.91^{\circ} \mathrm{C}$.

Pemanfaatan lahan di Desa Tugu Utara sebagian besar wilayah Desa Tugu Utara merupakan lahan perkebunan seluas 260,1 $\mathrm{Ha}$ sebagian lain sebagai perumahan/pemukiman seluas 18,3 $\mathrm{Ha}$, pekarangan seluas 10,2 Ha dan hutan lindung seluas $715 \mathrm{Ha}$.

Dilihat dari sektor perekonomian, sebagian besar Desa Tugu Utara bermata pencaharian Buruh Tani yaitu sebanyak 1.263 orang, Perkebunan sebanyak 750 orang, Pedagang sebanyak 556 orang, Buruh Bangunan sebanyak 315 orang serta Pengemudi sebanyak 215 orang. Sementara mata pencaharian lainnya yaitu Pegawai Negeri Sipil sebanyak 115 orang, Pengusaha Besar sebanyak 115 orang, Pengusaha Menengah 125 orang, Pengusaha kecil sebanyak 25 orang, TNI/Polri sebanyak 5 orang dan Pengrajin sebanyak 1 orang.

\section{HASIL DAN PEMBAHASAN}

\section{Pelaksanaan Program Pendidikan}

\section{Taman Belajar Cerdas Ceria (TABEL CC)}

Program yang dilaksanakan untuk TABEL CC mempunyai beberapa bagian yaitu TABEL CC PAUD dan SD. Tabel CC PAUD di ikuti oleh anak-anak usia 3-4 tahun dengan memberikan materi-materi dasar yang mudah seperti menempel, mewarnai dan menyanyi.

\section{Balai Pelatihan Komputer (BPLK)}

Program pelatihan komputer dilakukan dengan metode praktik serta teori dasar sebagai panduan, para pesrta dibimbing langsung oleh mahasiswa dalam pembelajaran, sasaran peserta pelatihan komputer ini yaitu anak usia Sekolah Menengah Pertama (SMP). 


\section{Pencak Silat}

Program pelatihan pencak silat dilakukan dengan metode praktik secara langsung bertatap muka dengan murid. Murid di bimbing langsung oleh mahasiswa dalam setiap latihan. Sasaran pencak silat yaitu anak usia sekolah dasar dan sekolah menengah pertama.

\section{Ekstrakurikuler Menari dan Menyanyi}

Mengasah bakat anak-anak dalam bidang menari dan menyanyi, untuk kegiatan menari, anak-anak kami ajarkan tariantarian tradisional dan untuk menyanyi kami ajarkan anak-anak menyanyikan lagu-lagu daerah untuk melestarikan budaya indonesia.

\section{Pendampingan Guru PAUD}

Dalam kegiatan pendampingan Guru PAUD ini kami melakukan metode awal dengan observasi ke 2 PAUD yang terdekat dengan kampung Ciburial RT 02 RW 05. Selanjutnya melakukan survei ke lokasi, dan observasi dengan menemui kepala sekolah PAUD. Observasi dilakukan melalui wawancara kepada Kepala Sekolah PAUD untuk menanyakan izin keikutsertaan dalam kegiatan mengajar di kelas. Melalui kegiatan pembelajaran di kelas kami dapat menemukan permasalahan-permasalahan yang ada di PAUD serta berdiskusi dengan Guru PAUD untuk meremukan solusinya.

\section{Seminar Pendidikan}

Sebuah proses akan pendidikan adalah berubahnya segala sesuatu menjadi sesuatu yang berbeda, ialah berupa nya sumber daya manusia yang memiliki harapan dan tujuan yang ingin dicapai.

\section{Posyandu}

Kemampuan masyarakat untuk mengembangkan kegiatan kesehatan dan kegiatan-kegiatan lain yang menunjang peningkatan kemampuan hidup sehat di masyarakat yang ikut berperan dalam kelangsungan program.

\section{Penyuluhan Kesehatan Masyarakat (PKM)}

Suatu kegiatan atau usaha untuk menyampaikan pesan kesehatan kepada masyarakat, kelompok atau individu. Dengan harapan bahwa dengan adanya pesan tersebut masyarakat dapat memperoleh pengetahuan tentang kesehatan yang lebih baik.

\section{Ekonomi Kreatif (keripik wortel, bola susu dan bucket bunga)}

Pelaksanaan kegiatan Ekonomi Kreatif ini dilakukan melalui pendekatan sosialisasi kepada tokoh masyarakat seperti ustadzah di pengajian yang membantu mensosialisasikan kegiatan dan memberikan pengetahuan awal manfaat dari kegiatan ekonomi kreatif ini, dan juga Ibu RT dan kader posyandu yang ikut serta mendukung sosialisasi kegiatan untuk ibu-ibu dan anak remaja.

Produk yang ditawarkan merupakan produk unggulan yang merupakan potensi sumber daya alam yang banyak di kampung Ciburial sehingga mudah didapat. Dalam Kegiatan Ekonomi Kreatif ini sudah dilakukannya uji coba terhadap produk yang akan di demonstrasikan kepada ibu-ibu dan anak remaja.

\section{Pengajian Anak-anak}

Pengajian anak-anak yang dilakukan di beberapa tempat yang dilaksanakan ba'da maghrib sampai ba'da isya dengan metode tahsin dan pemberian materi tentang tajdwidz, makharijul huruf dan doa seharihari.

\section{Pengajian Majelis Ta'lim}

Pengajian majelis ta'lim ini dilakukan dibeberapa tempat baik itu di Masjid maupun Mushola, dan kegiatan majelis ta'lim ini merupakan sarana untuk mendekatkan diri kepada Allah melalui pembacaan ratib dan shalawat. 


\section{Agustus}

Setiap tanggal 17 Agustus, bangsa Indonesia memperingati hari kemerdekaan. Serangkaian agenda mulai dari tingkat RT/RW pun diselenggarakan. Dari mulai persiapan upacara, perlombaan, menghias lingkungan dll yang membutuhkan kerjasama antar warga, agenda ini dapat menjadi media untuk bersosialisasi dan saling mengenal satu warga dan warga lainnya.

\section{Gotong Royong dan Bakti Sosial}

Bangsa indonesia memiliki budaya yang tidak dimiliki oleh bangsa lain yaitu budaya gotong royong, gotong royong dapat di pahami sebagai bentuk kerjasama aktif setiap orang untuk ikut terlibat secara langsung dalam kegiatan yang positif dan konstruktif, dimana di dalamnya ada nilai nilai kebersamaan mental, spiritual, penggabungan ketrampilan dan pemikiran atau nasihat yang sama yang dapat di pahami oleh masing - masing orang.

\section{Pembangunan Fisik Desa}

Pembuatan Tempat Sampah merupakan program kegiatan yang direncanakan berdasarkan hasil observasi di Kp. Ciburial Rt.02/05 bahwa warga masyarakatnya kurang menjaga lingkungan dengan membuang sampah ke sungai. Sehingga sampah menjadi menumpuk dan dibiarkan begitu saja. Sebagai solusinya yaitu membangun bak/tempat pembuangan sampah akhir. Sampah dipilah dan diolah terlebih dahulu sebelum dibakar.

\section{Pelatihan Tanaman Hydroponik}

Hidroponik adalah cara bercocok tanam tanpa media tanah, dan hanya membutuhkan air dengan larutan nutrisi dan media tanam separti serbuk kayu rokwool dan lain-lain sebagai pengganti tanah. Program pembelajaran hidroponik di selenggarakan di SD Negeri Tugu Utara 01 dengan sasaran peserta yaitu siswa-siswi kelas 6 (enam).

\section{Pola Hidup Bersih dan Sehat (PHBS)}

Pola hidup bersih dan sehat merupakan suatu pola perilaku menjaga kedisiplinan. Pola hidup bersih dan sehat dilaksanakan di SDN Ciburial dengan tema sampah, di dalam materi ini sampah ini menjelaskan mengenai dampak dari membuang sampah sembarangan dan penyakit yang ditimbulkan, dan juga membahas mengenai jenis-jenis sampah.

\section{PHBN HUT RI Desa Tugu Utara}

Dalam rangka memperingati HUT RI dari Desa biasanya membentuk kepanitiaan untuk melaksanakan kegiatan-kegiatan sebagai bentuk partisipasi kemerdekaan Indonesia. Terutama mahasiswa KKN masuk dalam anggota kepanitian.

\section{KESIMPULAN DAN IMPLIKASI}

\section{Kesimpulan}

Dengan adanya Kuliah Kerja Nyata ini sebagai salah satu program pengabdian kepada masyarakat, mahasiswa banyak memperoleh banyak sekali pengalaman dalam menggali serta menumbuhkan pemikiran memecahkan masalah.

Kuliah Kerja Nyata(KKN ) ini merupakan tempat mahasiswa untuk mengamalkan ilmu yang telah di dapatkan selama belajar di bangku perkuliahan.

Dengan adanya KKN di Desa Tugu Utara ini, masyarakat merasakan manfaatnya dengan adanya pengembangan sumber daya manusia dan pembangunan fisik desa yang berupa pembuatan tempat sampah, dan taman belajar cerdas ceria.

Kegiatan program yang selama ini kami laksanakan, semua telah terlaksana dan partisipasi masyarakat dengan kegiatan yang selama ini dilakukan sangat antusias.

Diantara program-program yang telah dilaksanakan, ada program unggulan dari kami yaitu Taman Belajar Cerdas Ceria PAUD dan Pembuatan Tempat Sampah. 
Ada beberapa program kelompok KKN yang ikut serta berpartisipasi dengan program kerja pihak Desa, organisasi masyarakat setempat, serta lembaga lembaga pemerintah maupun swasta yang menghasilkan kerjasama antar kelompok KKN dengan pihak yang terlibat.

\section{Implikasi}

Adapun implikasi dari hasil pelaksanaan kuliah kerja nyata ini yaitu sebagai berikut:

1. Mahasiswa kuliah kerja nyata Memiliki tali persaudaraan dengan warga masyarakat setempat.

2. Memberikan kesempatan kepada mahasiswa untuk terjun langsung ke dalam lingkungan masyarakat.

3. Menambah ilmu, pengetahuan, wawasan, dan pengalaman di dalam organisasi maupun kegiatan di lingkungan masyarakat.

4. Mahasiswa juga Mendapatkan pengalaman baru dalam lingkungan kemasyarakatan yang tidak ada selama diperkuliahan.

5. Kuliah kerja nyata (KKN) dapat Membangun rasa kebersamaan, gotong royong, solidaritas, tanggung jawab, dan saling menghargai satu sama lain di dalam organisasi KKN dan dalam kemasyarakatan.

6. Meningkatkan pengetahuan, keterampilan, dan perilaku anak-anak usia sekolah mulai dari tingkat PAUD, SD, dan SMP.

7. Menumbuhkan kesadaran masyarakatakan pentingnya suatu pendidikan anak, kesehatan, dan kebersihan lingkungan.

\section{UCAPAN TERIMAKASIH}

Kami ucapkan terima kasih sebesarbesarnya atas terselenggaranya Kuliah Kerja Nyata ini kepada Universitas Djuanda Bogor dan dan Badan Perencanaan Pembangunan Daerah (BAPPEDA) yang telah memberikan bantuan dan dukungan atas Program Kuliah Kerja Nyata (KKN).

\section{DAFTAR PUSTAKA}

Profil DesaTugu Utara

Repositori Stain Kudus. 2016. Kemandirian. Diunduh pada 19 Desember 2016 dari http://eprints.stainkudus.ac.id/658/5/5 \%20 BAB\%2011.Pdf 